\title{
EP4-mediated prostanoid signalling promotes oral cancer progression
}

\author{
Karen Sapienza ${ }^{1 *}$, Stewart Sale ${ }^{2}$, Angela Hague ${ }^{3}$, Ian R Hart ${ }^{1}$, John F Marshall ${ }^{1}$, Gareth J Thomas ${ }^{4}$ \\ From 16th International Charles Heidelberger Symposium on Cancer Research \\ Coimbra, Portugal. 26-28 September 2010
}

Cyclooxygenase-2 (COX-2) enzyme is upregulated in oral cancer (OSCC), where it catalyses $\mathrm{PGE}_{2}$ synthesis. We have shown previously that $\mathrm{PGE}_{2}$ promotes integrin-dependent OSCC invasion (1). $\mathrm{PGE}_{2}$ has four receptors (EP1-4), each coupled to different intracellular signaling pathways. We therefore investigated the role of EP receptor signaling in the invasive process.

We used immunochemistry and RT-PCR to examine EP receptor expression in OSCC cell lines and OSCC in vivo, and found marked upregulation of EP4. Chemical inhibition or transient knockdown of EP4 in OSCC lines significantly reduced levels of intracellular cyclic AMP $\left(\mathrm{cAMP}_{\mathrm{i}}\right)$, whereas EP4 overexpression increased $\mathrm{cAMP}_{\mathrm{i}}$. Using Transwell and organotypic invasion assays, we studied the functional role of EP4. Overexpression of EP4 promoted OSCC invasion, with confocal microscopy revealing that EP4 localized to filopodia, processes associated with cell motility. Conversely, inhibition of either EP4 or $\mathrm{CAMP}_{\mathrm{i}}$ suppressed invasion. Treatment of cells with the cAMP agonist, forskolin, restored invasion following $\mathrm{PGE}_{2}$ suppression. We identified the GTP-ase, Rac1, as a downstream target of $\mathrm{CAMP}_{\mathrm{i}}$, where inhibition of EP4 or cAMP $\mathrm{i}_{\mathrm{i}}$ suppressed Rac1 activation, and $\mathrm{RNA}_{\mathrm{i}}$ abrogation of Rac1 inhibited invasion.

Our data describe a novel signaling pathway in cancer invasion, and suggest that $\mathrm{COX}-2 / \mathrm{PGE}_{2}$-dependent OSCC signaling is primarily modulated through the EP4 receptor, leading to increased $\mathrm{CAMP}_{\mathrm{i}}$ and Rac1 activation. Targeting EP4 may be an important strategy to suppress tumor progression, and may avoid the sideeffects associated with systemic administration of COX-2 inhibitors.

\footnotetext{
* Correspondence: k.sapienza@qmul.ac.uk

'Centre for Tumour Biology, Institute of Cancer, Barts and the London School of Medicine, London, UK

Full list of author information is available at the end of the article
}

\section{Author details}

'Centre for Tumour Biology, Institute of Cancer, Barts and the London School of Medicine, London, UK. ${ }^{2}$ Cancer Biomarkers and Prevention Group, University of Leicester, Leicester, UK. ${ }^{3}$ Department of Oral \& Dental Science, University of Bristol, Bristol, UK. ${ }^{4}$ Experimental Pathology Group, Cancer Sciences Division, University of Southampton School of Medicine,

Southampton, UK.

Published: 24 September 2010

\section{Reference}

1. Nystrom ML, McCulloch D, Weinreb PH, Violette SM, Speight PM, Marshall JF, Hart IR, Thomas GJ: Cyclooxygenase-2 inhibition suppresses $\alpha_{v} \beta_{6}$ integrin-dependent oral squamous carcinoma invasion. Cancer Res 2006, 66:10833-10842.

doi:10.1158/0008-5472.CAN-06-1640

Cite this article as: Sapienza et al:: EP4-mediated prostanoid signalling promotes oral cancer progression. BMC Proceedings 2010 4(Suppl 2):P35.

Submit your next manuscript to BioMed Central and take full advantage of:

- Convenient online submission

- Thorough peer review

- No space constraints or color figure charges

- Immediate publication on acceptance

- Inclusion in PubMed, CAS, Scopus and Google Scholar

- Research which is freely available for redistribution 